\title{
RAZÃO PÚBLICA E PAISAGEM: REFLEXÕES E SUBSÍDIOS TEÓRICO-CONCEITUAIS PARA O ENTENDIMENTO E PARA A QUALIFICAÇÃO DA URBANIZAÇÃO CONTEMPORÂNEA ${ }^{1}$
}

\author{
PUBLIC REASON AND LANDSCAPE: REFLECTIONS AND SUBSIDIES FOR THE \\ THEORETICAL AND CONCEPTUAL UNDERSTANDING AND THE SKILLS OF \\ CONTEMPORARY URBANIZATION
}

Eugenio Fernandes Queiroga*

RESUMO

Este artigo apresenta uma discussão referente à esfera de vida pública na contemporaneidade, e apresenta uma formulação do conceito de "esfera pública geral", incluindo, além da esfera pública políitica, toda a vida em público. A partir da teoria da ação comunicativa elaborada por Habermas, fundamenta-se a expressão "razão pública". Tendo por base a noção de paisagem enquanto mediação entre sujeito que percebe e formas, agentes e ações percebidas, discute-se o papel ativo da paisagem enquanto dimensão pública, constitutiva dos processos socioespaciais no meio urbano. Dessa maneira, a relevância da paisagem e do projeto para a qualificação do cotidiano e da esfera pública nas cidades brasileiras precisa ser melhor considerada, sobretudo para a constituição da cidadania (domínio das liberdades), mais do que simples crescimento do mercado consumidor interno (domínio das necessidades).

Palavras-chave: Esfera pública. Razão pública. Paisagem. Urbanização contemporânea. Paisagismo.

\section{ABSTRACT}

This paper presents a discussion about the public sphere in contemporary and presents the concept of "general public sphere", including, besides the political public sphere, all the public life. The theory of communicative action developed by Habermas is the base to the concept of "public reason". The notion of landscape as mediation between perceiver and forms, agents and actions perceived is the base to it discusses the active role of landscape as public dimension constitutive of social-space process in urban areas. The relevance of landscape and of landscape design (architecture, urban and planning) for the qualification of everyday life and the public sphere in Brazilian cities must be better considered, especially for the constitution of citizenship (domain liberties), rather than simple growth of domestic consumer market (domain needs).

Keywords: Public sphere. Public reason. Landscape. Contemporary urbanization. Landscape architecture.

Este artigo é uma versão revisada e adaptada para publicação da palestra inicial proferida no $11^{\circ}$ Encontro Nacional de Ensino de Paisagismo em Escolas de Arquitetura e Urbanismo no Brasil - ENEPEA. Campo Grande (MS), 2012.

Arquiteto e Urbanista, mestre, doutor, livre-docente em Arquitetura e Urbanismo pela Faculdade de Arquitetura e Urbanismo da Universidade de São Paulo (FAUUSP). Professor associado da FAUUSP e bolsista do Conselho Nacional de Desenvolvimento Científico e Tecnológico (CNPq). Rua do Lago, 876, Cidade Universitária, São Paulo, SP, Brasil.

queiroga@usp.br 


\section{INTRODUÇÃO}

O tema desta palestra, razão pública e paisagem, entendo ser da mais alta relevância para a qualificação da urbanização contemporânea, notadamente no Brasil, onde continuam enormes as desigualdades sociais, refletidas e reforçadas nas paisagens, onde a contribuição do paisagismo ainda é muito menor do que poderia ou deveria ser.

Ingênuo seria trazer ou esperar receitas de boa forma, de procedimentos práticos capazes, por si só, de reverterem o quadro negativo de boa parte das ações que produzem o espaço e a paisagem urbana contemporânea. Nossa pretensão é grande, mas, evidentemente, não vai nesse sentido.

que se intenciona é apresentar algumas reflexões e formulações teóricas que podem contribuir para o entendimento da urbanização atual, notadamente sobre o papel das relações entre razão pública e paisagem neste processo.

Ambiciona-se colocar tais questões para o debate público, e que dele possam sair propostas de ações mais atentas à qualificação e conservação de paisagens que interessem aos cidadãos e ao exercício da cidadania, ainda que se reconheça haver, no país, uma cidadania bastante incompleta, ou, talvez, por isso mesmo.

Iniciarei por uma reflexão sobre as esferas de vida (pública, privada, do cotidiano) que, juntamente com a teoria da ação comunicativa habermasiana, fundamenta a expressão conceitual denominada "razão pública". Em seguida, discutirei o papel ativo da paisagem enquanto dimensão pública constitutiva dos processos socioespaciais. Concluirei com breve discussão acerca da relevância da paisagem e do projeto.

Importa, ainda preliminarmente, dizer que não se trata de reflexões teóricas concebidas isoladamente e à distância da realidade brasileira. Tive a grata satisfação de realizar, de maneira coletiva, ampla pesquisa sobre sistemas de espaços livres e a constituição da esfera pública contemporânea no Brasil - através da constituição da Rede Nacional de Pesquisa QUAPÁ-SEL -, estudando a maioria das capitais do país, algumas metrópoles interioranas, aglomerados urbanos e algumas (poucas) cidades médias.

Foi, sobretudo, do intenso embate com as paisagens urbanas brasileiras e do estimulante debate realizado com colegas pesquisadores de todas as regiões do país que se formularam as ideias que exponho a seguir. Nenhum deles deve, no entanto, ser responsabilizado pelas incorreções e más interpretações que posso vir a fazer a seguir.

\section{SOBRE AS ESFERAS PÚBLICA, PRIVADA, SOCIAL E COTIDIANA: COM ARENDT "CONTRA" SENNETT}

Deve-se a Hannah Arendt a construção inicial do conceito de esfera de vida pública. Segundo Arendt (1991) o termo "público" expressa dois fenômenos correlatos, mas não idênticos:

- tudo o que vem a público pode ser visto e ouvido por todos, abrangendo a maior divulgação possível; 
- o próprio mundo, na medida em que é comum a todos e diferente do lugar que nele nos cabe; o mundo não é a terra ou a natureza como espaço limitado e condição geral da vida, mas, enquanto artefato, é um produto humano, mundo feito pelo homem.

Arendt (1991) denomina vita activa as três atividades humanas fundamentais: labor, trabalho e ação (política). O labor é atividade correspondente aos processos biológicos do corpo humano. $O$ trabalho é a atividade relacionada ao artificialismo da existência humana. A ação é prerrogativa do homem, e só ela depende inteiramente da constante presença de outros - logo, sua condição é a pluralidade. Na antiguidade romana, viver era sinônimo de "estar dentre os homens", e morrer, de "deixar de estar dentre os homens".

A esfera de vida correspondente às ações é, portanto, a esfera pública, envolvendo as atividades pertinentes a um mundo comum, lembrando que, para Arendt (1991, p. 62), " [...] a esfera pública, enquanto mundo comum, reúne-nos na companhia uns dos outros e contudo evita que colidamos uns com os outros [...]".

Para Aristóteles, de todas as atividades humanas, somente duas eram consideradas políticas e constituintes do que denominava bios politikos: a ação (práxis) e o discurso (lexis), constitutivos da "esfera dos negócios humanos", que exclui tudo o que seja apenas necessário ou útil (ARENDT, 1991).

Para que os homens (cidadãos) pudessem se dedicar à esfera pública, era necessário que outros (escravos) Ihes dessem a condição material para tanto. Assim, o trabalho e - labor constituíam atividades próprias da esfera de vida privada, necessários para a manutenção da vida. A distinção entre as esferas pública e privada correspondia à existência das esferas da política e da família como entidades separadas, desde o surgimento das cidades-estado.

Mais do que simples oposição, as esferas de vida púbica e privada eram complementares. $\bigcirc$ forte papel público dos cidadãos gregos ou romanos não se faria sem:

- base material construída sobre trabalho escravo (privado), que permitisse aos cidadãos destinar parte expressiva de seu tempo para a vida pública;

- moral que valorizasse a ação pública - política em sentido amplo.

A sociedade grega e, em maior escala, a romana, estabeleceram coesa relação entre ideologia, economia, política e Estado, que lhes permitiv enormes avanços culturais nas mais diversas áreas, da filosofia às artes, passando pelas ciências e pela cultura do cotidiano, notadamente em sua esfera pública.

Arendt (1991) deixa claro a progressiva desvalorização da esfera pública. Primeiro, com a ascensão dos valores do cristianismo e a instauração de sua hegemonia na Idade Média; depois, pelo surgimento da esfera social, que se interpôs entre a esfera privada e a esfera pública, fazendo diminuir: 
- a relevância da esfera pública na caracterização do Estado, seja pelo declínio das repúblicas e pelo avanço das monarquias absolutistas, seja na modernidade, pelo distanciamento dos cidadãos em relação aos assuntos de Estado;

- a relevância das famílias (esfera privada) na economia (domínio das necessidades), com a constituição de empresas cada vez maiores, com o consequente aumento de seu poder econômico, político e ideológico.

Arendt (1991) identifica o declínio da esfera pública (até os anos 1950) como questão estrutural, tanto nas sociedades de massa de regimes liberais quanto nos regimes autoritários, na medida em que se fortalece a esfera social enquanto elemento central das estruturas econômicas.

Arendt (1991) compreende estruturalmente as transformações ocorridas na modernidade com o fortalecimento da esfera social. Já Sennett (1998) e o senso comum lamentam o declínio do homem público por meio da crescente valorização da esfera privada. Sem dúvida, tal fato ocorreu, mas deixa-se de perceber o porquê dessa valorização. Naturaliza-se equivocadamente o processo social, quase como se a crescente valorização da esfera privada fosse um gesto autônomo e não um fenômeno engendrado pelos processos estruturais e ideológicos da sociedade capitalista moderna.

A criação de consumidores (mais do que de cidadãos) na democracia burguesa dá aos atores hegemônicos um poder de controle que vai da orientação dos gastos públicos às agendas do desenvolvimento científico, passando pelo controle ideológico dos meios de comunicação de massa (figura 1).

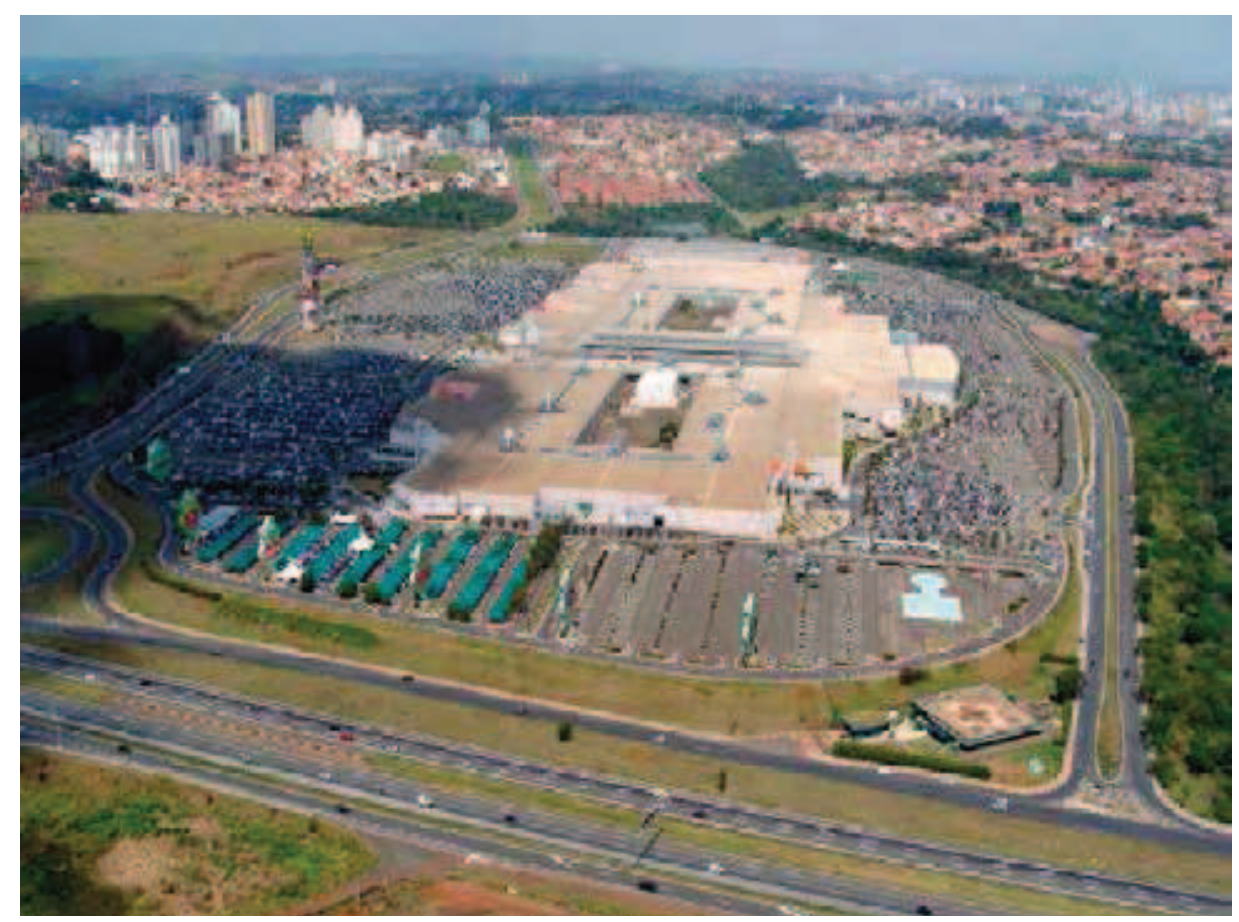

Figura 1 Gigantesco shopping center em Campinas (SP): apologia ao consumo, convivência seletiva e controlada. Foto: Silvio Macedo - 2008. 
Para Arendt (1991), o declínio da esfera pública se relaciona ao fortalecimento da esfera social. Para Sennett (1998), o declínio do homem público é consequência do crescimento da esfera de vida comunitária, na qual cresce o desejo pela segurança, de estar entre iguais, vivendo-se (alienando-se) confortavelmente em guetos sociais, tais como os subúrbios estadunidenses ou os inúmeros loteamentos fechados que se produzem na urbanização contemporânea brasileira.

A leitura sennettiana encontra fácil aceitação, sobretudo, por sua evidente visualidade em algumas paisagens habitadas por estratos de renda média. Além disso, cunhar sempre pejorativamente a noção de comunidade é ação redutora que não contribui para o entendimento da contemporaneidade.

Segundo Rogério Proença Leite (2004, p. 309):

Sennett, talvez, por não admitir a necessidade de reconhecimento público das comunidades, termina por não fazer uma distinção nítida entre o que ele chama de Gemeinschaft destrutiva e outras formas de 'comunidades' urbanas que, embora também territorializem seus códigos de identificação, mantêm suas fronteiras em contínua negociação e disputam com outras diferentes 'comunidades'. Ainda que Sennett se refira a um tipo específico de gueto urbano, cuja dimensão geográfica segmentaria o espaço urbano em 'territórios íntimos' ou em 'territórios da indiferença', comete, a meu ver, um duplo equívoco. O primeiro quando afirma que esse tipo perverso de 'fraternidade comunal' é a forma de socialização predominante na vida urbana contemporânea, o segundo, por concluir, a partir disso, que o espaço público está morto.

Com o propósito de não reduzir a noção de comunidade à visão sennettiana, opta-se pela expressão esfera de vida cotidiana. A esfera cotidiana atravessa as esferas de vida privada, social e a esfera pública, trazendo, portanto, ao mesmo tempo, noções de relação e complexidade que melhor capacitam a teoria para enfrentar as totalidades concretas, dentre as quais as paisagens urbanas brasileiras. Não há esferas de vida estanques, como se, à maneira positivista, fosse possível compreender a realidade a partir de separações, classificações e hierarquias.

A esfera do cotidiano corresponde, em termos espaciais, ao que Lefebvre (2009) denominou "espaço percebido": o espaço da prática social, dos sentidos, da produção e da reprodução, do trabalho e do lazer, definido, em suma, pela vida cotidiana.

\section{SOBRE ESFERA PÚBLICA E ESFERA PRIVADA: DE ARENDT A HABERMAS}

Segundo Avritzer e Costa (2004, p. 705):

O conceito de esfera pública representou um elemento central no processo de reconstrução da teoria crítica na segunda metade do século XX (Habermas, 1990; Calhoun, 1992; Thompson, 1995; Melucci, 1996). Significou a continuação de uma 
tradição crítica sobre a cultura de massas iniciada pela Escola de Frankfurt (Jay, 1973) e, ao mesmo tempo, produziu uma grande mudança dentro desta tradição, através da recuperação de um fundamento normativo que permitiu estabelecer uma nova relação entre teoria crítica e teoria democrática.

Em sua tese de livre-docência, publicada originalmente em 1962, Habermas se posiciona criticamente quanto à perda de valor da esfera pública na sociedade capitalista. Mais do que falar em "declínio do homem público", investiga as mudanças fundamentais ocorridas na esfera de vida pública, realizando análise estrutural das relações sociais.

Enquanto Arendt constrói o conceito de esfera pública de forma estrita, sem adjetivações, Habermas, ao verificar (mais que idealizar) o conceito na totalidade concreta, discorre sobre várias esferas públicas: a burguesa (dominante) e a plebeia, a política e a politicamente ativa (esta última, a rigor, pode ser considerada como equivalente ao conceito arendtiano de esfera pública), literária, democrática, plebiscitária, interna à organização, parlamentar, manipulada, helênica, refeudalizada, esfera pública da Corte, da grande família. Dessa maneira, o autor de Mudança estrutural da esfera pública deixa claro que:

- a esfera pública não é um conceito puro, absoluto, mas constituído e caracterizado historicamente;

- é possível a constituição de esferas públicas (no plural) para um mesmo momento histórico.

Evidentemente, tais esferas públicas se entrelaçam e se relacionam às esferas privada e íntima (para utilizar as expressões habermasianas).

Para Habermas (1984), a esfera privada inclui o mercado e a família, sendo esta última caracterizadora da esfera íntima. Observa-se aí mais uma distinção em relação à obra de Arendt (1991), publicada originalmente três anos antes da tese de livre-docência de Habermas. Vale destacar, além das diferenças e correlações de nomenclatura, a estrutura de pensamento dos autores.

Habermas vê a esfera da família (íntima) como integrante da esfera do mercado (esfera privada). Já Arendt vê a superação da esfera da família (esfera privada) pela esfera do mercado (esfera social). O raciocínio arendtiano procura não se desligar dos tipos da antiguidade clássica - esfera pública e esfera privada -, vendo na modernidade o fortalecimento da esfera social; iá Habermas não se ocupa tanto da antiguidade clássica, interessado que está em compreender as transformações da esfera pública desde a modernidade.

Para Habermas, a esfera pública criada na sociedade burguesa é mais complexa, uma vez que acompanha, em escala, o avanço, a organização e a sofisticação ideológica das sociedades capitalistas. Vê a importância do crescente público leitor, do surgimento dos jornais e dos cafés parisienses enquanto espaços da esfera pública. Compreende a formação do Estado moderno e suas instituições públicas como 
elemento da esfera pública das sociedades democráticas burguesas, sejam as casas legislativas enquanto palco do debate político, seja o fortalecimento dos direitos civis, políticos e sociais graças à inclusão crescente de diferentes parcelas da sociedade ao mundo da cidadania.

Trata-se, evidentemente, de processo lento e contraditório: na Revolução Francesa, a primeira voz feminina a levantar-se a favor do direito do voto das mulheres foi guiIhotinada. Nos Estados Unidos, primeira república moderna, garantiu-se amplo direito às diferentes práticas religiosas (dos brancos), e as últimas normas de apartheid foram abolidas somente na década de 1960.

Nas sociedades capitalistas democráticas, ser cidadão é ter seus direitos civis respeitados, inclusive o direito de alienar-se politicamente. Por outro lado, em tais sociedades garante-se, também, o direito - dos que possuem capital - de explorar recursos naturais e humanos, acumulando riquezas privadamente. Esse fato, sem dúvida, ocorreu nas sociedades complexas pré-capitalistas, porém não se constituía no maior valor reconhecido socialmente, como se observa com o avanço - econômico e ideológico do capitalismo.

\section{RAZÃO PÚBLICA E ESFERA PÚBLICA GERAL: UMA PROPOSIÇÃO DIANTE DA CONTEMPORANEIDADE}

Desde a publicação da Condição humana, de Arendt, e da Mudança estrutural da esfera pública, de Habermas, até o presente já se vai meio século. As transformações socioespaciais foram enormes:

- a aceleração científica resultou na estruturação do que Milton Santos (1996) designou como "meio técnico-científico informacional";

- a globalização e a imposição de padrões culturais e ideológicos dos países centrais para os demais vêm resultando em rearranjos geopolítico-econômicos expressivos - a queda do muro de Berlim, a dissolução da União Soviética, a formação da União Europeia e demais grandes blocos econômicos no final do século XX e início do século XXI, a participação econômica crescente de China, Índia, Brasil e Rússia no mercado global - permitem que esses países reivindiquem novo papel no concerto das nações.

Não ocorreram somente transformações geopolíticas, mas, também, nas variadas escalas da esfera pública política, para usar a expressão habermasiana. $\bigcirc$ constante interesse de Habermas no trato da tríade conceitual (formada por "esfera pública", "discurso" e "razão"), mantido por mais de cinquenta anos, torna o autor referência (quase) obrigatória aos que estudam ou lançam mão do conceito de esfera pública.

Discutem-se algumas ideias do filósofo alemão, tomando-o como referência para a compreensão e para a elaboração de proposição sobre o conceito de esfera pública. Para compreender a visão habermasiana sobre a esfera pública, inclusive a contempo- 
rânea, é necessária a leitura de obras fundamentais do autor, como Teoria da ação comunicativa e Direito e democracia, respectivamente dos anos 1980 e 1990, além de livros de ensaios mais recentes (anos 1990 e primeira década deste século) sobre filosofia política².

Na década de 1980, Habermas publica sua teoria da ação comunicativa, segundo a qual a ação não é apenas ação política em sentido estrito, como na proposta de Arendt (1991), mas composta por discursos que se põem em debate visando ao entendimento mútuo entre os interlocutores, estabelecendo uma razão intersubjetiva, processual, comunicativa. Dessa maneira, Habermas (1990, p. 290) propõe uma superação do debate entre razão subjetiva e razão objetiva: "Em cada acto de fala o locutor refere-se simultaneamente a algo no mundo objectivo, num mundo social comum e no seu mundo subjetivo."

A razão comunicativa (libertadora) é própria do cotidiano - do "mundo da vida", na expressão habermasiana (1990, p. 291) - e contrapõe-se, dialeticamente, à razão sistêmica (opressora) - instrumental -, dos atores econômicos-hegemônicos e do Estado. Não se trata de anulação do conflito por idealização, a partir da ideia de "entendimento mútuo"; pelo contrário, a dialética se impõe, concreta e cotidianamente, no choque entre as racionalidades comunicacionais e as sistêmicas. Tampouco existiria uma "[...] razão pura que só posteriormente tivesse vestido as roupas linguísticas. $\bigcirc$ que há é uma razão encarnada, à partida, em contextos de agir comunicativo como em estruturas do mundo de vida". (HABERMAS, 1990, p. 297).

A razão comunicativa é a base para a noção de razão pública. Para Habermas (2006), a "esfera pública" é o espaço do trato comunicativo de uns com os outros. Dessa maneira, o autor lê, na contemporaneidade, em sua pluralidade democrática, novos estágios e riscos para a "esfera pública", como as novas dimensões políticas que se estabelecem na União Europeia, criando uma "esfera pública europeia" para além dos Estados-nações, porém, gerando, dialeticamente, um agravamento das questões étnico-nacionais no velho continente.

Outra questão que inspira a reflexão contemporânea de Habermas (2006, p. 129130) sobre a "esfera pública" é a relação entre Estado laico, democrático e pluralista e as perspectivas do naturalismo e da religião, em que o autor vê, na coexistência quase sempre pacífica de diferentes visões de mundo (garantida pelo Estado de direito), um exercício da razão pública dos diferentes grupos sociais.

Para o filósofo, a norma jurídica, ditada de cima para baixo, não é suficiente para explicar essa relação pacífica entre, por exemplo, ateus, protestantes e católicos na América do Norte, existindo, de fato, o entendimento racional público da noção de alteridade como uma verdade intersubjetiva entre os referidos grupos sociais, ainda que processual e falível.

Embora se aceite, em parte, a crítica a Habermas, por sua teoria da ação comunicativa privilegiar o consenso, é necessário lembrar que a razão comunicativa entre

2 Dentre eles: Habermas $(2001,2006,2007)$. 
sujeitos se estabelece processualmente no embate discursivo, na discussão, sendo que, tanto sua duração como sua validade relacionam-se ao tempo do consenso. Assim como o consenso não se constitui um dominante, o mesmo se deve dizer do dissenso. Ambos são fundamentais para a história, inclusive a história do cotidiano. São pares dialéticos do processo social.

Habermas, em Direito e democracia (2003), continua sua crítica ao Estado, tendo claro que o núcleo do poder político não absorve de maneira direta os fluxos comunicacionais gerados pela sociedade, cabendo aí importante papel para uma "esfera pública periférica" (redes de comunicação não institucionais), que, por insistência em suas manifestações, pode levar seus temas ao núcleo do sistema político, superando visões estabelecidas e conservadoras.

A consideração do cotidiano, desde a Teoria da ação comunicativa (1987), possibilita inferir relações entre as esferas do cotidiano e a pública, permitindo avançar para além de certo "purismo nostálgico" presente na noção de "esfera pública" arendtiana. Não se trata de negar a contribuição original e fundamental de Hannah Arendt, mas de buscar uma teoria mais adequada à compreensão do presente, sem perder o valor de sua perspectiva crítica.

Para Habermas, as novas mídias de informação e de telecomunicação são também integrantes da "esfera pública", sendo, evidentemente, aquelas mais abertas, como a internet, as mais adequadas ao debate político.

Na maior parte das vezes, no entanto, essas mídias de tanta eficiência técnica para difusão de informações, não têm seu uso voltado para o debate público-político stricto sensu, motivo pelo qual Habermas (2006) distingue dois tipos de esfera pública:

- uma voltada para a questão da autorrepresentação daqueles que alcançam visibilidade e popularidade; aqui, o público é plateia;

- outra relacionada aos debates político, científico, filosófico e artístico, nos quais os discursos se rebatem resultando em razão pública, em uma esfera pública políica.

Proponho, além disso, denominar esfera pública geral a toda a vida "em público", incluindo, portanto, o debate público (político e intelectual), a ação comunicativa, inclusive cotidiana, e qualquer outra ação que se compartilhe "em público", seja no espaço real, seja no virtual.

Não se trata de relação de oposição entre esfera pública política (esfera pública em sentido estrito) e esfera pública geral. A esfera pública geral inclui a esfera pública política, não apenas como um conjunto que contém outro conjunto, mas sistêmica e dialeticamente, de sorte que o que ocorre numa esfera modifica a outra, em movimento dialético entre todo (esfera pública geral) e parte (esfera pública política).

Há que se reconhecer qualidades na vida "em público" mesmo nas ações cotidianas não intencionalmente políticas, seja um passeio familiar num parque público aos fins de semana, o andar pela cidade após uma jornada de trabalho, o convívio público 
num botequim carioca, numa padaria paulistana ou num café parisiense. $\bigcirc$ convívio público, voluntário ou involuntário, possui um grau de civilidade que, em harmonia ou em conflito, já se constitui parte da vida pública. A vida em público é elemento para a consciência da alteridade, base potencial para a ação (política) arendtiana, ou comunicativa, habermasiana.

Nesse sentido, a esfera pública política - esfera pública stricto sensu - seria como a ponta de um iceberg, cuja totalidade inclui compreender toda a vida em público, a esfera pública geral - esfera pública lato sensu (figura 2).

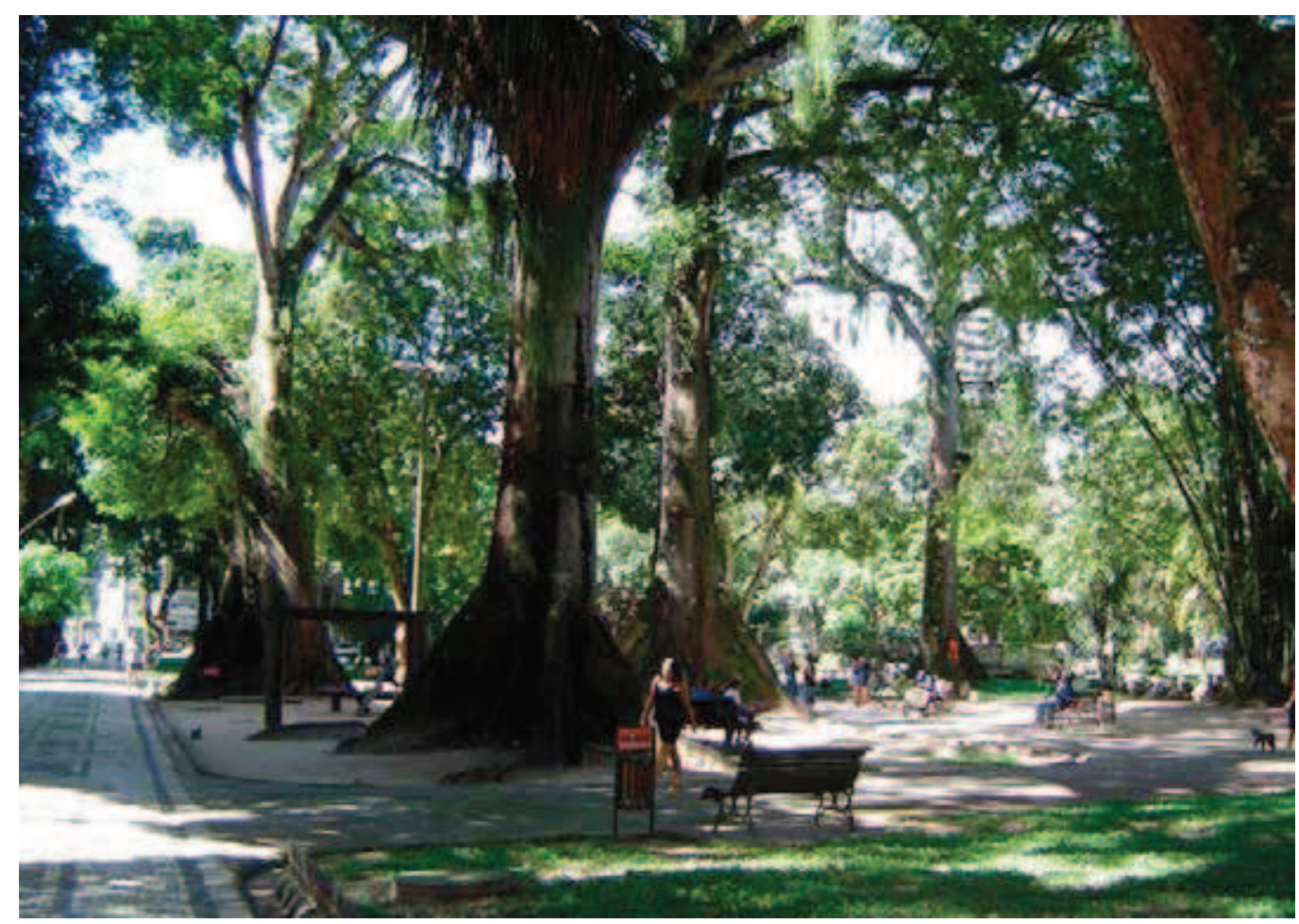

Figura 2 Praça Batista Campos, em Belém (PA). Espaço de múltiplas apropriações públicas, locus da esfera pública geral.

Foto: Eugenio Fernandes Queiroga - 2007.

Vale lembrar que a comunicação em público não se reduz à linguagem verbal. A maneira de se vestir e de se apresentar em público, de usar e apropriar-se das paisagens urbanas são também formas (não verbais) de comunicação. As práticas espaciais "em público" de cada grupo social são formas de comunicação não verbal, constituindo-se, em parte, da esfera pública geral.

Reitera-se que a esfera pública contemporânea, seja ela em sentido estrito ou geral, não possui, como suporte, apenas os espaços físicos ditos públicos. Novos meios midiáticos e telecomunicacionais permitem a publicação de eventos e ações em tempo real, e não são todos, ou de todo, controlados pelos agentes hegemônicos. A docilidade técnica contemporânea permite aos homens novas formas de comunicação e representação (SANTOS, 2000), muitas, inclusive, apenas se iniciando neste novo século. 
Não se trata de um meio destruindo outro: as telecomunicações e redes informacionais não anulam a importância do espaço concreto; o virtual não substitui o real. Novas relações sociais vêm demonstrar que ambas se potencializam. Um evento num espaço público se transmite pela internet a partir de um pequeno telefone celular, de um tablet, dando ao evento dimensão pública que pode alcançar o planeta em tempo real. Manifestações públicas no espaço real são organizadas com grande suporte comunicacional via internet com frequência cada vez maior, sejam protestos públicos do porte dos ocorridos na Primavera Árabe, sejam manifestações internacionais de gênero, sejam, em escala local, manifestações por motivos mais diversos: contra a derrubada de uma árvore em praça de bairro de elite, contra este ou aquele prefeito mais ou menos corrupto.

\section{UMA PERSPECTIVA SOBRE O CONCEITO DE PAISAGEM}

São muitas as acepções e os conceitos sobre paisagem para nós, arquitetos, que lidamos com ela enquanto objeto de pesquisa, ensino, extensão, projeto, planejamento e gestão, valendo transitar por várias áreas do saber - da filosofia à geografia, passando pelas artes, inclusive pela poesia - no intuito de enriquecer nossa percepção e nosso entendimento sobre este objeto, por natureza, complexo. Tal trânsito não se pode realizar sem rigor, sem o qual se corre o risco de produzir apenas falas (mal) recheadas de metáforas, quando necessitamos, por dever de ofício, compreender e propor paisagens para as sociedades.

Inicio esta reflexão por notas de um dos maiores poetas do século XX. Fernando Pessoa, em nota preliminar do Cancioneiro (2005, p. 1), disse o seguinte:

1.

Em todo o momento de atividade mental acontece em nós um duplo fenômeno de percepção: ao mesmo tempo que temos consciência dum estado de alma, temos diante de nós, impressionando-nos os sentidos que estão virados para o exterior, uma paisagem qualquer, entendendo por paisagem, para conveniência de frases, tudo o que forma o mundo exterior num determinado momento da nossa percepção.

2.

Todo o estado de alma é uma paisagem. Isto é, todo o estado de alma é não só representável por uma paisagem, mas verdadeiramente uma paisagem. Há em nós um espaço interior onde a matéria da nossa vida física se agita. Assim uma tristeza é um lago morto dentro de nós, uma alegria um dia de sol no nosso espírito. [...]

3.

Assim, tendo nós, ao mesmo tempo, consciência do exterior e do nosso espírito, e sendo o nosso espírito uma paisagem, temos ao mesmo tempo consciência de duas paisagens. Ora, essas paisagens fundem-se, interpenetram-se, de modo que o nosso estado de alma, seja ele qual for, sofre um pouco da paisagem que estamos vendo [...] e, também, a paisagem exterior sofre do nosso estado de alma [...] 
Da perspectiva pessoana, bem como a partir da fenomenologia, pode-se inferir que a paisagem supera a dicotomia sujeito-objeto. A paisagem está na relação entre sujeito e objeto, atravessando, ou melhor, transitando sincronicamente entre a subjetividade e a materialidade (figuras 3 e 4).

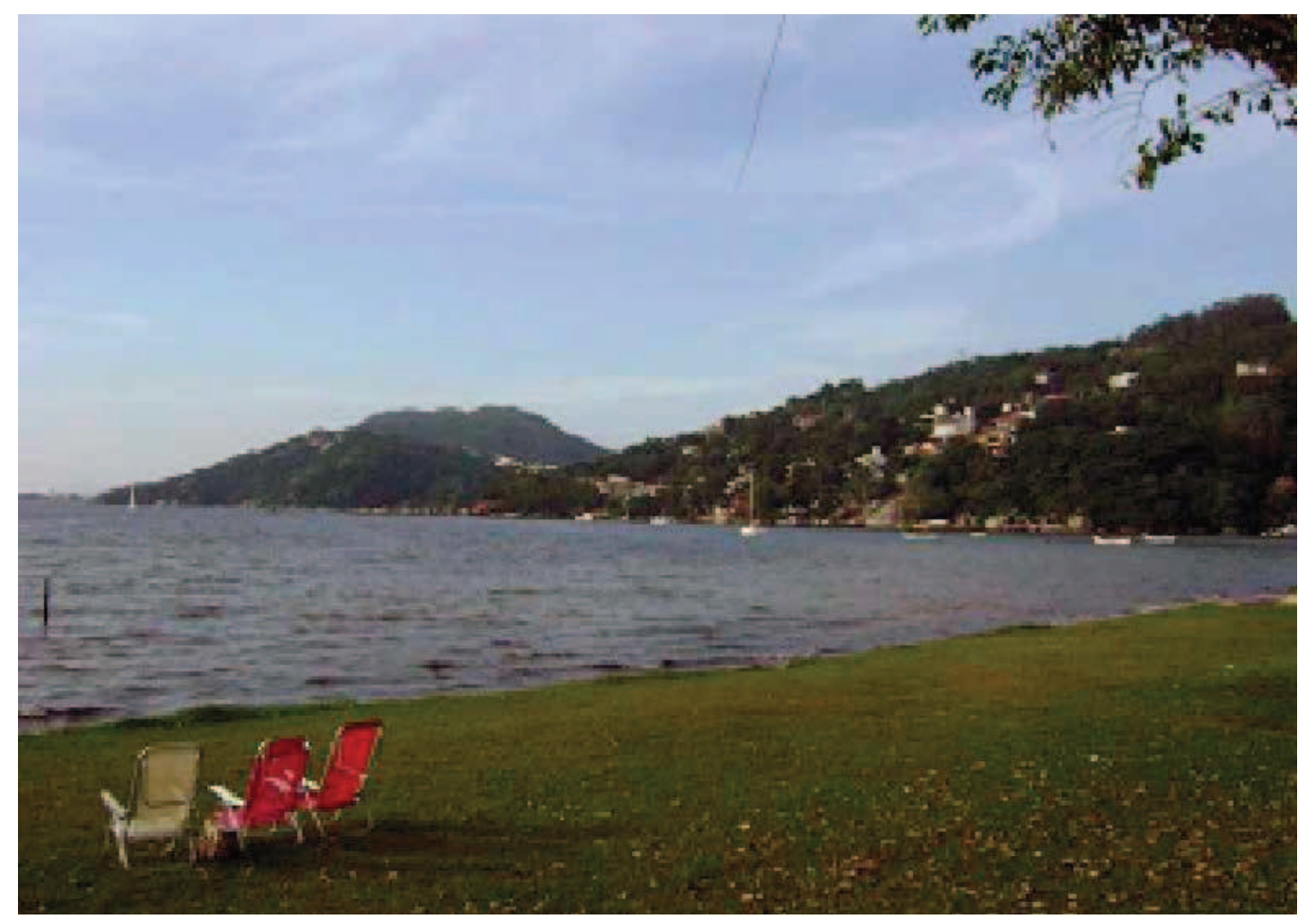

Figura 3 Estado da alma e paisagem. Lagoa da Conceição, Florianópolis (SC). Foto: Eugenio Fernandes Queiroga - 2007.

Lembro-me de uma aula de pós-graduação de Miranda Magnoli, nos anos 1980, apoiada no, também poeta, Verlaine, dizendo que "a paisagem é retrato da alma". Por outro lado, Magnoli também nos ensina que a paisagem é resultado, sempre dinâmico, da interação entre os processos sociais e os processos naturais.

A paisagem, portanto, não é apenas a configuração espacial - forma, materialidade, sistema de objetos -, mas também inclui o domínio da percepção espacial, aí influindo tanto os aspectos objetivos exteriores e interiores a quem observa a paisagem, quanto os aspectos subjetivos - culturais, simbólicos - de quem a produz e de quem a vivencia. Inclui, portanto, as formas enquanto formas percebidas, mas não se apreende apenas os objetos geográficos, urbanísticos, arquitetônicos, sinais gráficos e outros elementos visuais, iá que contemplar e estar numa paisagem inclui perceber relações mais complexas entre sistemas de objetos e ações. Nesse sentido, a paisagem aproxima-se do espaço no sentido miltoniano do termo, pois as ações manifestam-se - direta ou indiretamente - na paisagem.

As pessoas estão diretamente na paisagem, "são" na paisagem, movimentam-se nos espaços livres, são pedestres, ciclistas, motoristas e passageiros, dando vida às 
vias públicas. Utilizam os espaços livres para os mais diversos fins, do lazer à manifestação pública.

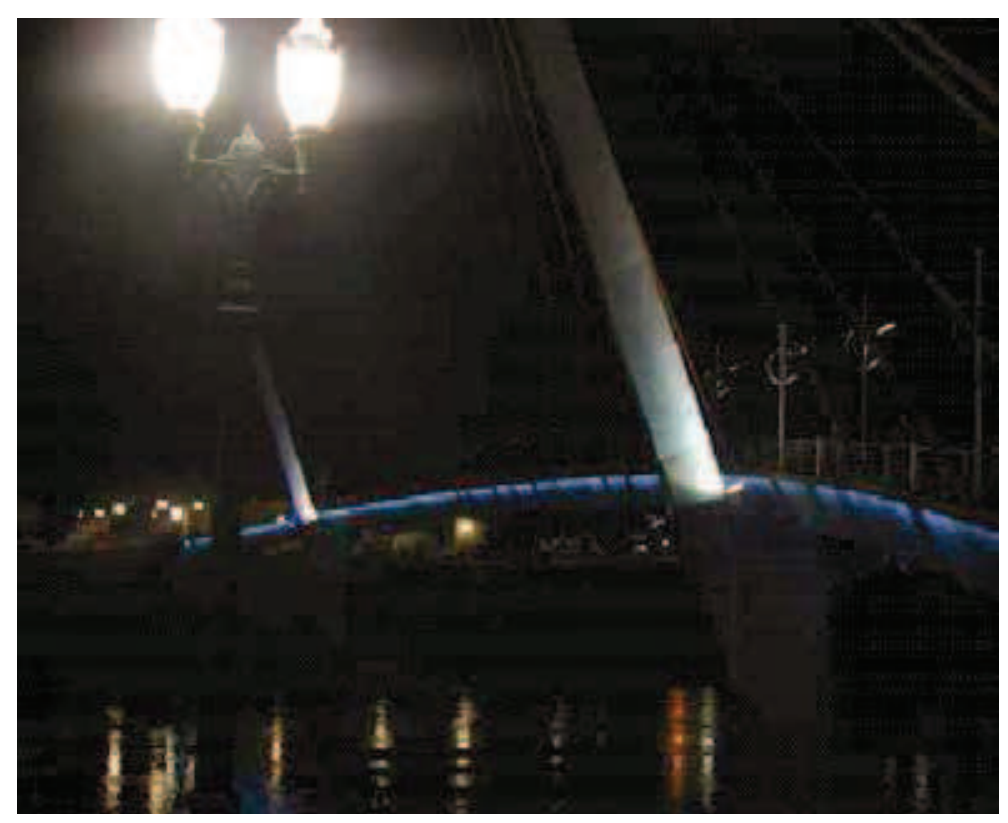

Figura 4 Paisagem e estada da alma. Ponte de pedestres sobre o rio Acre, Rio Branco (AC). Foto: Eugenio Fernandes Queiroga - 2012.

As pessoas, instituições e empresas produzem e apropriam-se dos espaços edificados e livres, construindo e alterando paisagens urbanas, agrícolas e rurais. A paisagem brasileira contemporânea, ainda que produzida, em grande medida, a partir de interesses "individuais" de pessoas físicas e jurídicas, é obra social, e seu resultado, sempre dinâmico, é coletivo.

Enquanto categoria interna do espaço, a paisagem se distingue do espaço pelo que a enriquece e, ao mesmo tempo, a limita: a dimensão perceptiva. $\bigcirc$ espaço total nunca é redutível a uma paisagem, pois, mesmo que um astronauta possa contemplar, à distância, a Terra no seu "todo", o espaço total, certamente, inclui sistemas de objetos que não se apresentam diretamente sobre a paisagem, como as redes de infraestrutura subterrâneas ou submersas.

O espaço total apresenta incontáveis ações que não se apresentam diretamente à percepção enquanto paisagens: do aumento da taxa de juros a inúmeras ações da esfera de vida privada. Por outro lado, pode passar despercebido do estudioso do espaço geográfico o som e o movimento de um pequeno bambuzal ao passar do vento, a luz prateada da lua cheia sobre um terreiro de café, o silêncio de uma grande avenida na madrugada. Não se trata de lirismo de um romantismo tardio, mas de atenção a incontáveis qualidades paisagísticas do espaço que não se capturam por imagens de satélite, fotos aéreas ou pelo georreferenciamento de dados censitários.

É a experiência da paisagem - da contemplação externa à sua imersão atenta que permite praticá-la. A paisagem é parte do cotidiano de todos, mas não é, a todo 
momento, objeto de atenção das pessoas, visto que, na vida cotidiana, nem sempre se está em condições ou mesmo com o interesse de observá-la.

A menor apreensão e apreciação das paisagens contribuem, sem dúvida, para que interesses individuais (de pessoas e empresas) as desqualifiquem sem maiores discussões públicas. Isto, infelizmente, é processo cada vez mais comum na maioria das grandes cidades brasileiras (figura 5).

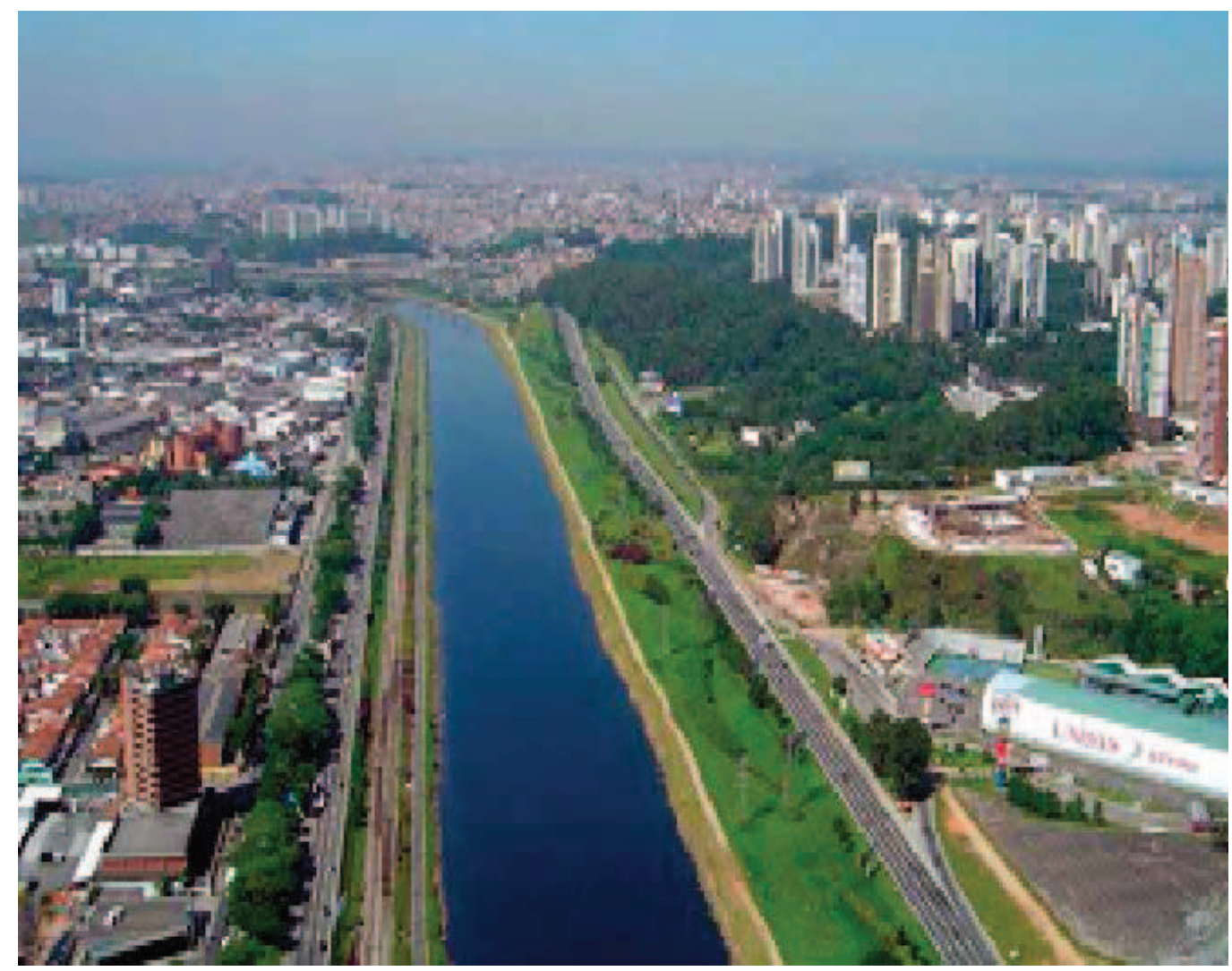

Figura 5 Rio Pinheiros, em São Paulo (SP). Esgoto a céu aberto, margens ocupadas por vias expressas, várzeas impermeabilizadas, (ir) racionalidade capitalista.

Foto: Acervo QUAPA - 2005.

A apreensão das paisagens, banais ou excepcionais, envolve quase sempre uma dimensão pública (figura 6). Para todos que trafegam uma via pública, no campo ou na cidade, é possível apreender a paisagem. Mesmo diante da janela de um apartamento, a vista privada, privilegiada ou não, que se tem da cidade - com seus prédios e espaços livres privados e públicos - forma, no seu conjunto, uma paisagem pública.

Em essência, a paisagem é pública, é de sua natureza apresentar-se a todos, ainda que parcelas da paisagem possam ser reivindicadas por determinados grupos sociais, dificultando a apreensão pública de determinadas paisagens. São exemplos: algumas reservas indígenas, por necessidade de sobrevivência, algumas favelas, por imposição da violência, alguns loteamentos fechados, por desprezo ao público dos grupos que se autossegregam. 


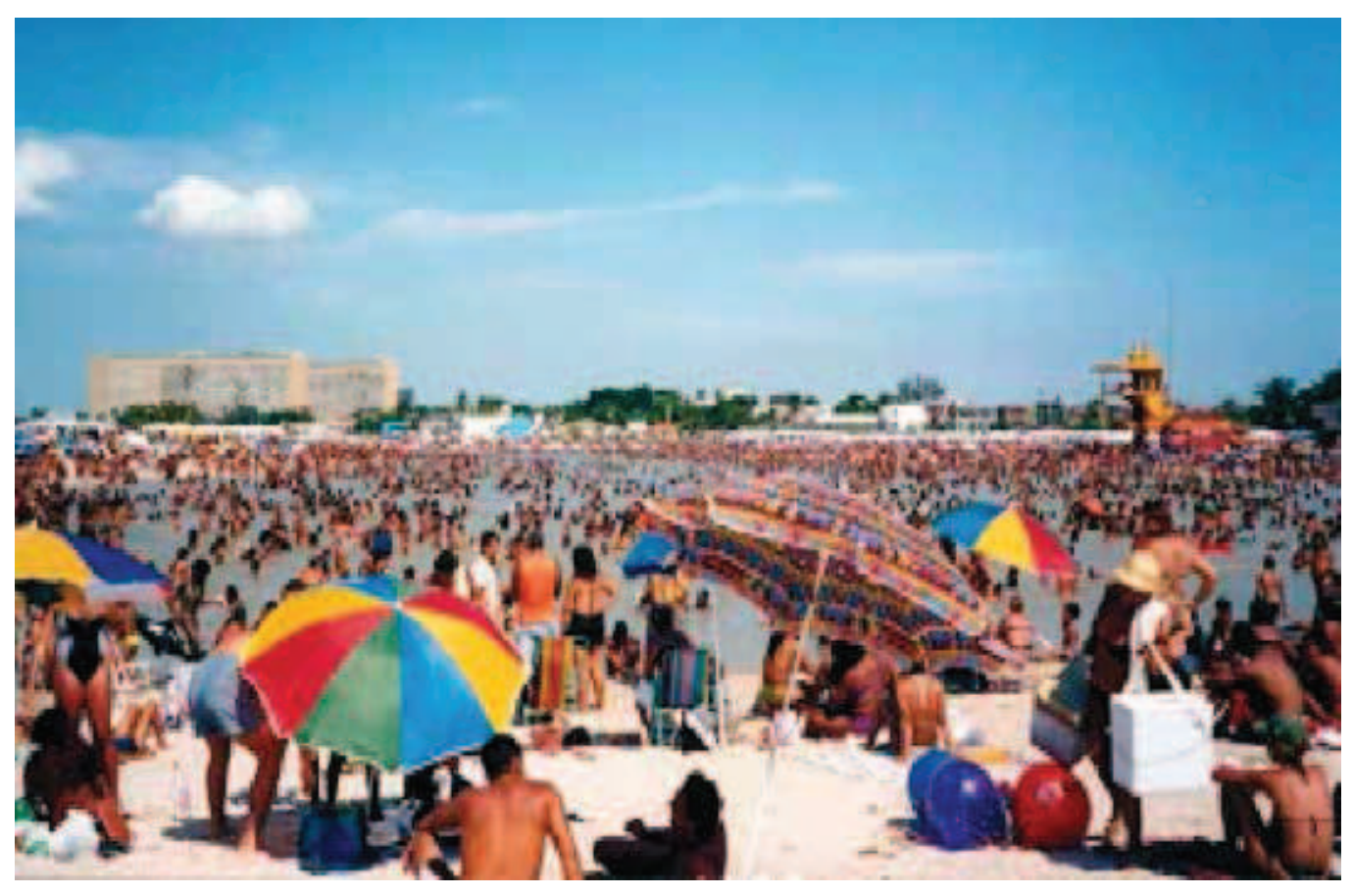

Figura 6 Piscinão de Ramos, Rio de Janeiro (RJ). Desfrute público da paisagem. Foto: Acervo QUAPÁ - 2005.

Há, de certo, momentos em que a leitura da paisagem se empobrece, caso das avenidas cercadas por muros de loteamentos fechados, da monotonia de grandes conjuntos habitacionais recém-implantados, do arrasamento de uma floresta para posterior aproveitamento como pastagem; noutros, chama atenção a desqualificação e a degradação ambiental, como as águas fortemente poluídas de rios e baías cercadas por vias expressas ou habitações precárias.

Por outro lado, mesmo paisagens banais podem ser bastante queridas por seus vivenciadores, caso em que os exemplos são desnecessários - porque óbvios. Basta fechar os olhos e todos serão capazes de lembrar-se de paisagens ao mesmo tempo singelas e admiradas em locais visitados seja uma única vez, seja cotidianamente.

A importância da apreensão pública das paisagens se coloca, então, não apenas para a conservação de paisagens excepcionais, mas, também, para que se possa valorizar, no domínio da razão pública, as paisagens banais do cotidiano.

Paisagens urbanas, agrícolas ou rurais, podem incluir formas que evocam a natureza - primeira ou segunda -, contribuindo para a consciência de sua existência por meio da sensibilidade de sua apreensão e vivência, permitindo valorizá-las.

A maioria das paisagens urbanas permite algum grau de fruição pública. Pode ser prazeroso apenas o caminhar pela cidade, sobretudo quando há segurança, conforto e interesse pela diversidade de situações ao longo de percursos não estabelecidos, descobertos. A paisagem pode evocar sentimentos de memória, afetividade e pertencimento. $\bigcirc$ contrário também ocorre: estranhamento, receio, insegurança, situações ambientalmente desagradáveis. 
De qualquer forma, a paisagem sempre informa sobre os lugares do mundo a quem se propõe a lê-la com atenção. Tal atitude deveria ser imperiosa ao arquiteto, ainda que ele se ocupe de outras áreas propositivas que não o paisagismo (figura 7).

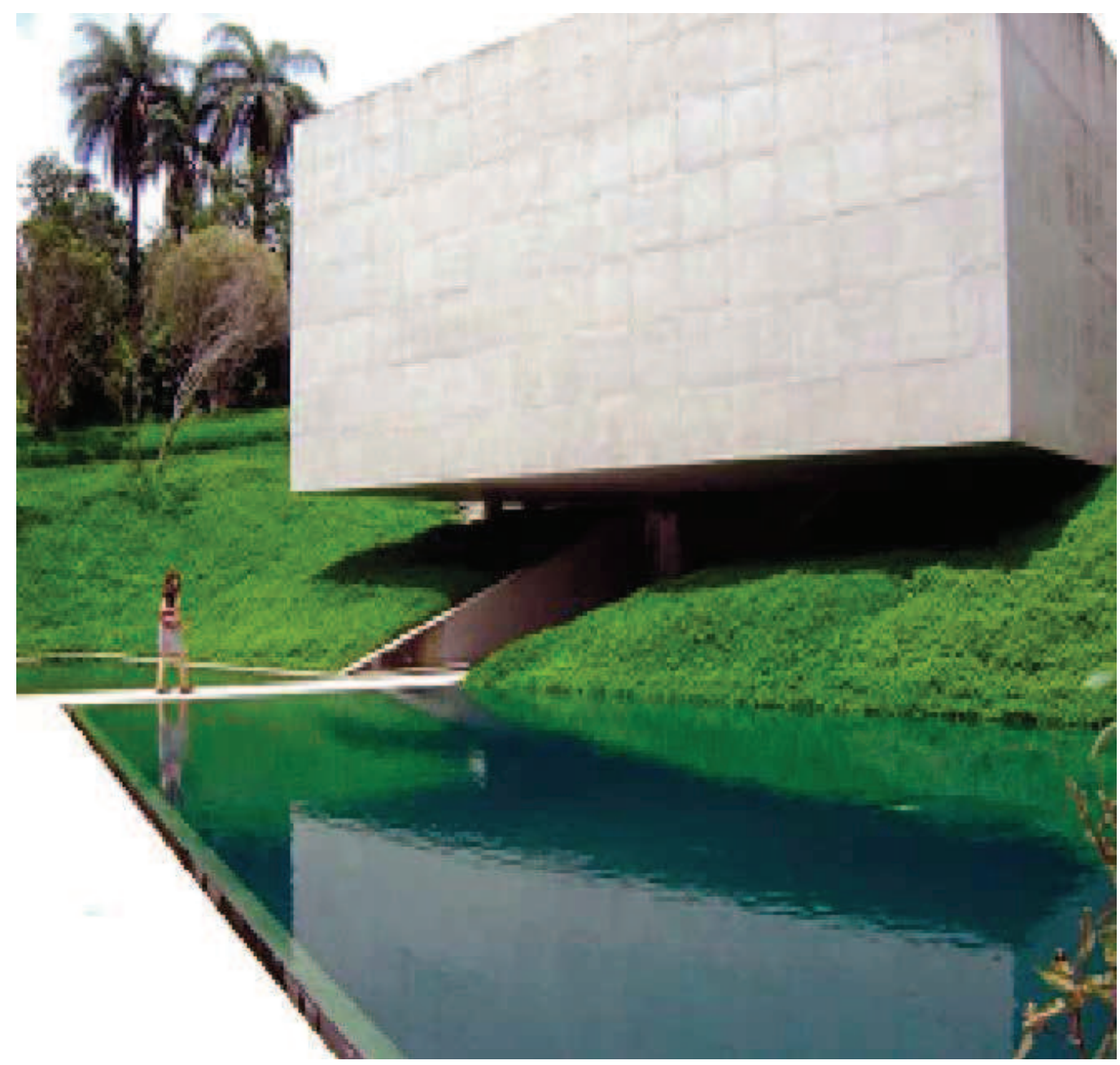

Figura 7 Pavilhão de Adriana Varejão em Inhotim, Brumadinho (MG). Notável integração entre arte, arquitetura e paisagismo.

Foto: Eugenio Fernandes Queiroga - 2009.

As paisagens se constituem em elemento identitário público de diferentes grupos sociais, com significados distintos para cada um, seja na escala dos lugares e das regiões, seja de maneira mais abstrata e simbólica na escala do território nacional.

O direito à paisagem não deve ser encarado como algo a se conquistar somente depois que se satisfizerem direitos mais elementares, como os relacionados à moradia, educação e saúde. A qualificação da paisagem integra a melhoria do habitat e do ambiente, bem como potencializa maior uso dos espaços públicos, relacionando-se, portanto, às questões da habitação, educação, saúde, do ambiente, enfim, à qualidade de vida (figura 8). 
A desqualificação das paisagens deveria indignar os cidadãos, incitando-os contra tais atitudes, seja de pessoas, empresas ou instituições. No entanto, isso é prática ainda pouco comum no Brasil, até há poucas décadas rural, pouco alfabetizado e que só no século XXI viu sua população tornar-se majoritariamente de renda média (média-baixa, sobretudo).

Importante iniciar ações de conscientização sobre a relevância pública da paisagem, sobretudo na escala dos lugares, pois são os subespaços de maior apreensão e experiência cotidiana (figura 9).

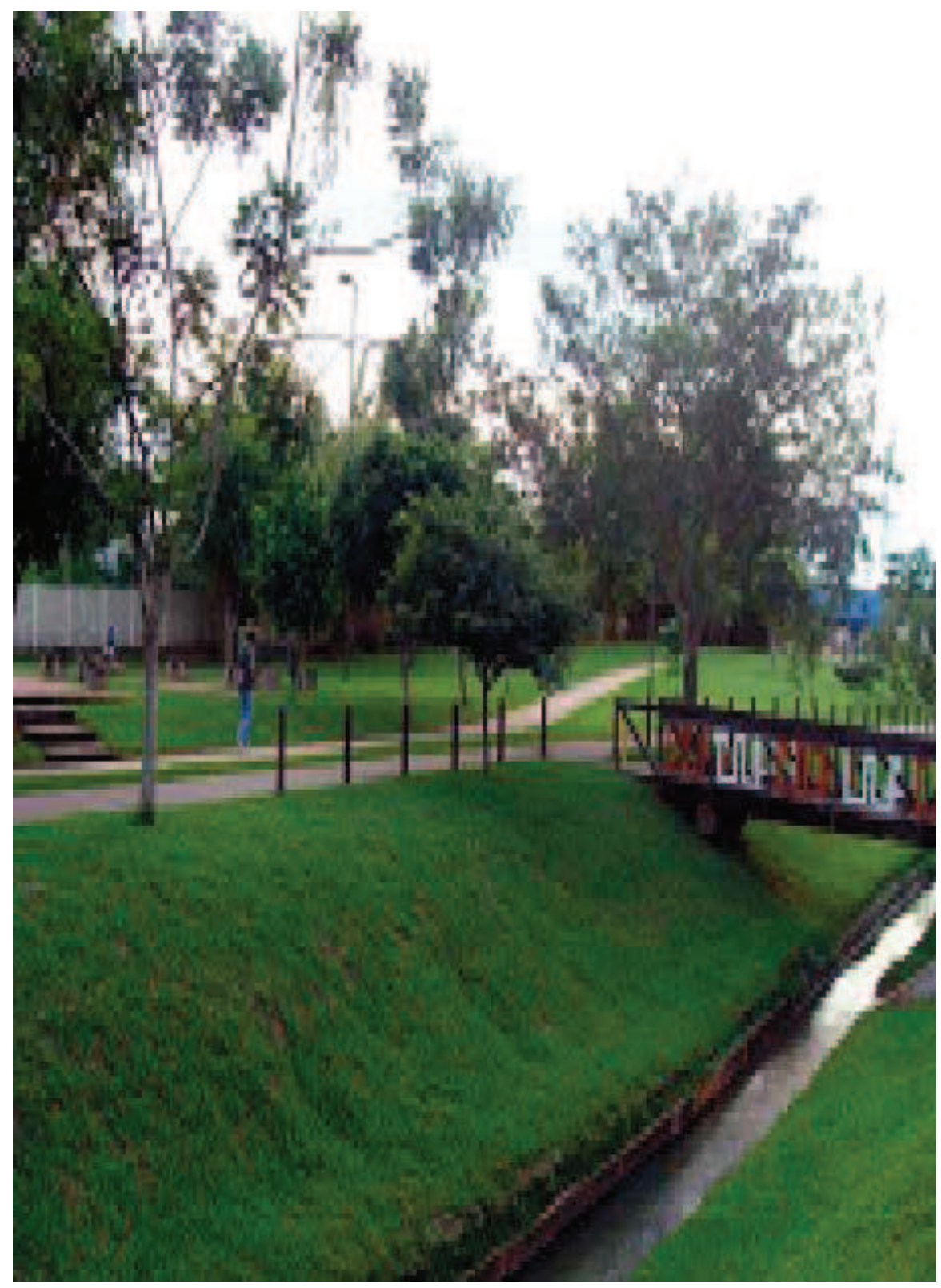

Figura 8 Parque Tucumã, integrante do sistema de parques lineares de Rio Branco (AC). Saneamento básico e espaços adequados ao lazer público.

Foto: Eugenio Fernandes Queiroga - 2012. 


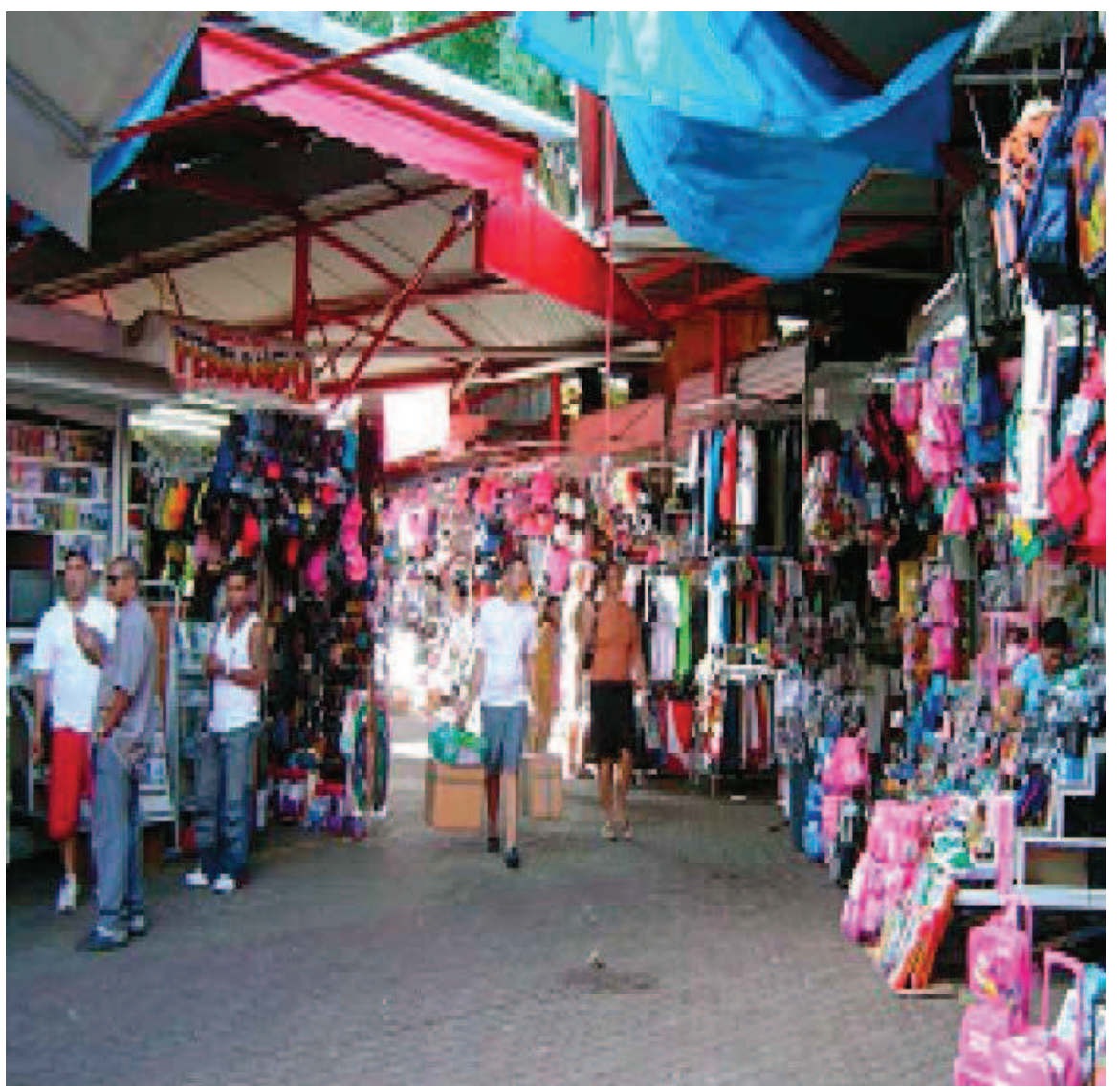

Figura 9 Camelódromo junto ao Terminal Vicente Cury, em Campinas (SP). Espaço de forte apropriação pública cotidiana.

Foto: Eugenio Fernandes Queiroga - 2005.

\section{DA RELEVÂNCIA DA PAISAGEM E DO PROJETO}

Segundo Maria Angela Leite (1998, p. 81):

O processo de construção da paisagem é um processo histórico de representação das relações sociais, através do qual práticas e ideologias tornam-se realidades materiais pela transformação de seu significado em ordem efetiva dos objetos sobre o território. Promover essa transformação significa tornar o geral visível como situação concreta local, conferindo caráter distintivo, complexo e, frequentemente, contraditório ao conjunto de conceitos que constitui o mundo. Significa, em síntese, criar lugares. A paisagem assim entendida revela uma dimensão de projeto, implícita no ato de reunir objetos em pontos potencialmente capazes de desencadear transformações culturais.

A paisagem não é, portanto, apenas herança ou trabalho morto (realizado). Enquanto categoria interna ao espaço, ela inclui e transcende a fisionomia do sistema de objetos, pois envolve o sistema de ações que anima sua materialidade, que compõe o 
espaço total. Para além de sua aparência, a paisagem é existência que se transforma a cada movimento da sociedade e dos fenômenos biofísicos (figura 10).

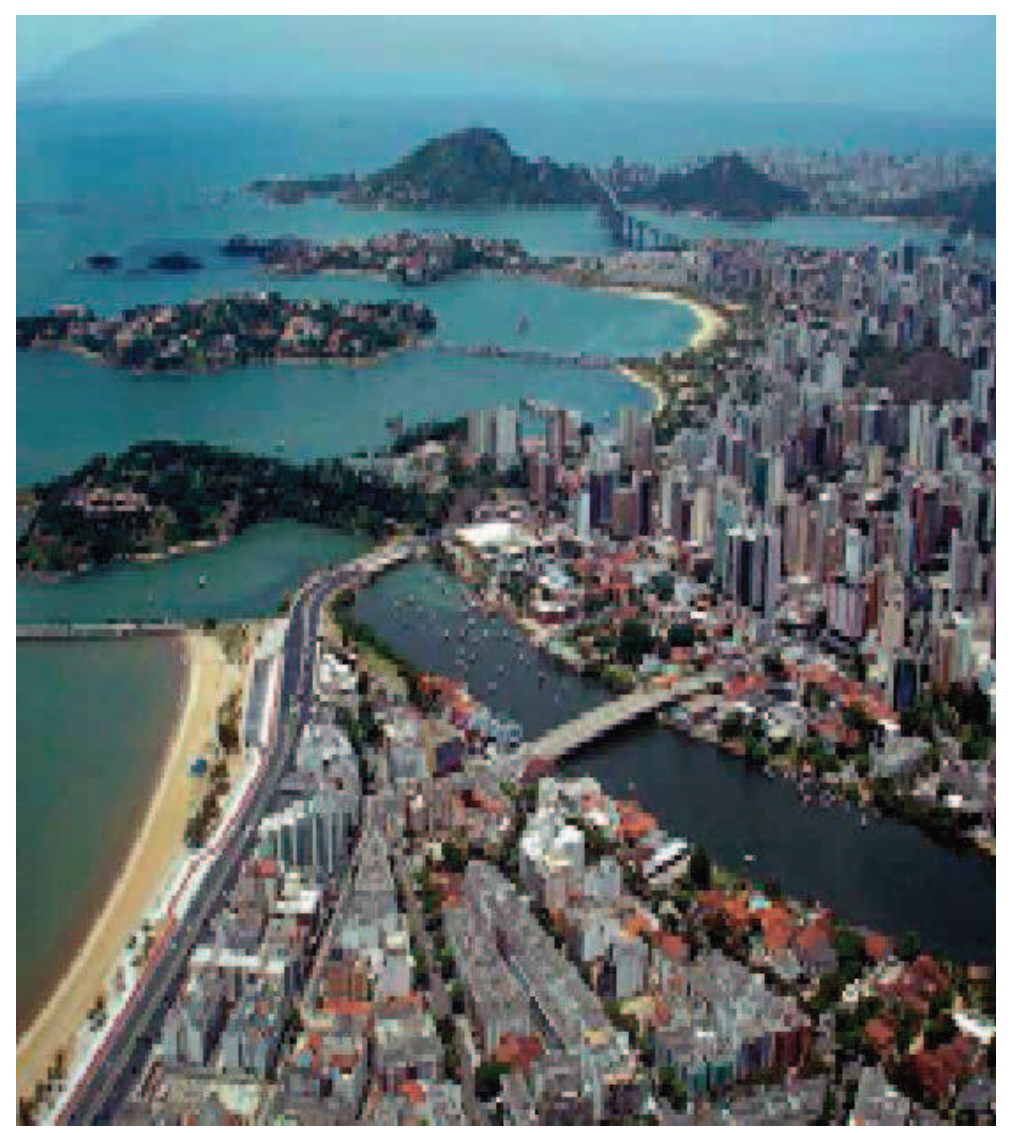

Figura 10 Vista parcial de Vitória (ES). Dinâmicas naturais e processos sociais configuram sua paisagem peculiar. Foto: Acervo QUAPÁ - 2009.

As ações (humanas) são portadoras de intencionalidades, realizando-se no presente, embora visem ao futuro. O homem é projeto, já dizia Sartre (1973), ainda que apresente o passado e sua materialidade pretérita como herança, como prático-inerte, na acepção sartreana, rugosidade que "desacelera" o futuro de maneira desigual em cada lugar. A ação visa ao porvir imediato ou distante, individual ou coletivo. Se o homem é projeto, a paisagem, criação sempre presente do homem, também o é. A paisagem indica projetos, iá realizados ou em processo, como índices para o futuro, para perspectivas, potencialidades.

Sobre as paisagens, homens, empresas e instituições constroem, no cotidiano, seus planos de dominação ou de solidariedade. $O$ projeto da paisagem se apresenta como manifestação cultural no espaço, seja elaborado por um arquiteto ou por uma equipe multidisciplinar integrada a grupos sociais em processo criativo participativo. Projetar envolve a potência do novo, ainda que seja um projeto de restauro da paisagem, mesmo em situações de fortes limitações econômicas, sociais e ambientais (figura 11). 


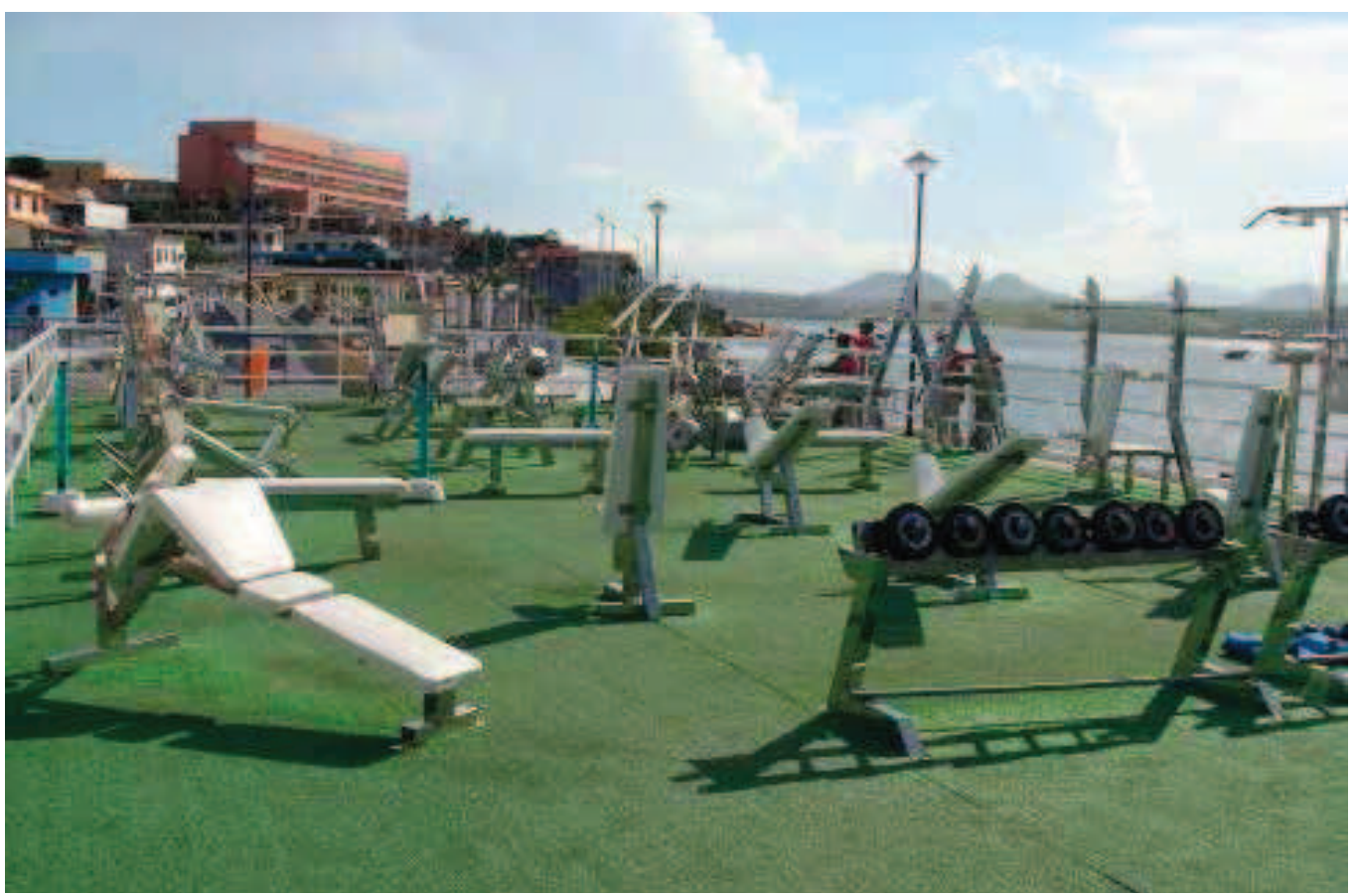

Figura 11 Equipamentos de musculação em praça, na Baía Noroeste de Vitória (ES), área periférica da cidade. Foto: Silvio Macedo - 2008.

Na contemporaneidade, não faltam ações e ideologias antagônicas à razão pública, contrárias à cidade enquanto espaço de convivência e sistema de lugares públicos. São muitas as arquiteturas, os urbanismos e paisagismos que privilegiam a vida privada, a fragmentação, o isolamento, sob a ideologia hipócrita do rótulo "sustentável". Propostas de valorização da "natureza", alienando e segregando classes sociais, são situações cada vez mais frequentes no país e no mundo.

Por outro lado, há discursos e práticas sobre a paisagem que vão ao encontro do fortalecimento da ideia de cidade enquanto locus da vida pública, no país e no exterior, desde políticas promovidas por diversas municipalidades até ações de grupos coletivos em periferias de grandes metrópoles, passando por projetos paisagísticos participativos que, ao mesmo tempo, valorizam recursos ambientais e propiciam intensa vida pública. Há projetos de espaços públicos potencialmente educadores, bem como educadores participando de novas práticas - críticas e criativas - sobre a paisagem do cotidiano. São iniciativas que denomino como próprias de um paisagismo crítico (QUEIROGA, 2006), em que a participação popular é levada a sério, produzindo-se não apenas trocas de saberes, mas conhecimento novo, onde as dimensões públicas da paisagem são valorizadas.

Cada vez mais tais iniciativas deixam de se constituir pontos isolados e integram redes culturais de informação e comunicação, como solidariedades orgânicas. De Bogotá a Copenhague, passando por favelas, periferias, bairros operários ou de melhor renda no Brasil: Ilha das Caieiras, Campolim, Brasilândia, Rocinha, Canal da Maternidade, Região do Campo Grande, em Campinas, vilas nos morros de Belo Horizonte ou de 
Porto Alegre. No entanto, não há ilusão quanto à disparidade entre as áreas (muito maiores) dos novos empreendimentos excludentes perante a escala das ações inclusivas realizadas no país.

É necessário, porém, atentar para todos os processos, não apenas os hegemônicos, levando em conta as qualidades e não só as quantidades; as contradições dos investimentos bilionários; as resistências opacas, e não apenas o que brilha na mídia e no mercado oficial. A beleza pode ser outra, não a do grande edifício-monumento, mas dos lugares públicos do cotidiano, das paisagens banais requalificadas (figura 12).

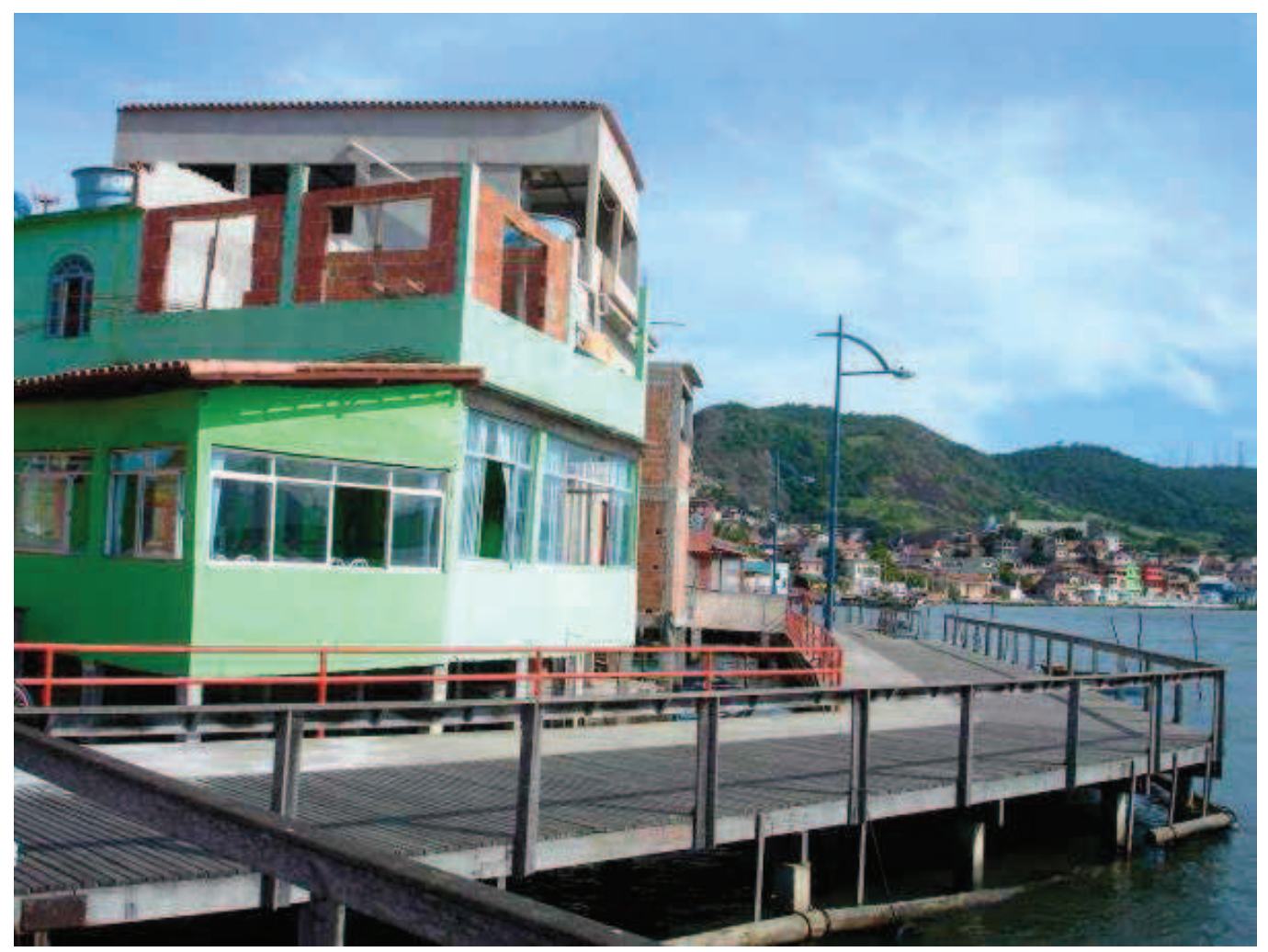

Figura 12 Orla tratada na llha das Caieiras, periferia de Vitória (ES). Foto: M. London - 2008.

O novo patamar ao qual chegou a sociedade brasileira impõe metas mais ambiciosas. Não basta zerar o alarmante déficit habitacional apenas de maneira quantitativa, nem tampouco erradicar o analfabetismo ou o trabalho infantil. É necessário que a cidade potencialize a cidadania, que haja espaços de expressão pública, de produção cultural para todos (independentemente de seu estrato de renda), que o centro seja também na periferia.

Não é suficiente incluir no mercado de trabalho e de consumo milhões de brasileiros, retirando-os da miséria, indigência e pobreza. Há muito a ser feito, incluindo-se qualificar os espaços para a esfera pública - do cotidiano às manifestações de maior escala, das calçadas aos parques, das ciclovias às praças, aos novos espaços de encontro público, estejam onde estiverem (figura 13). 


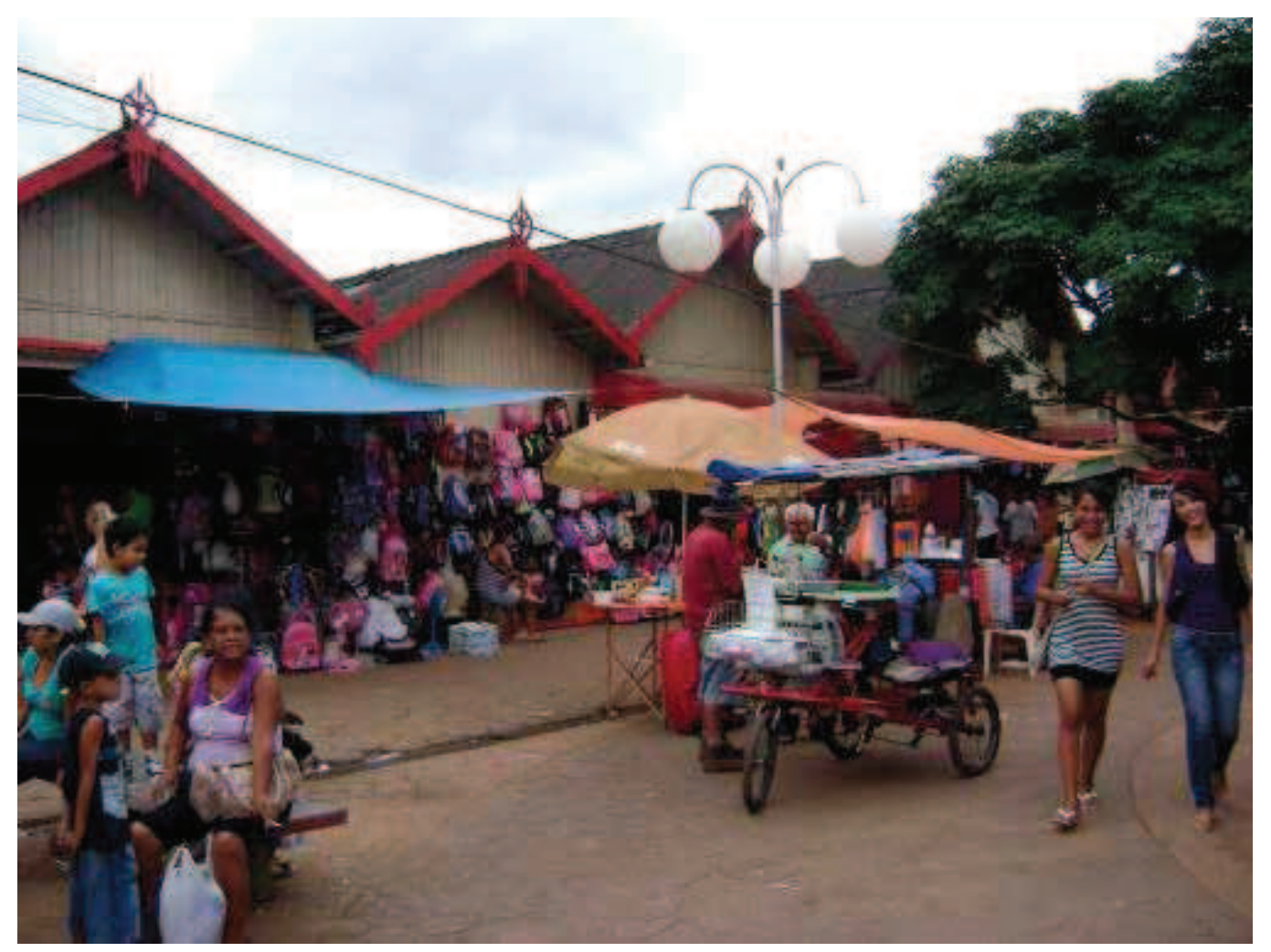

Figura 13 Comércio popular em Rio Branco (AC). Mais que espaço de consumo, espaço de convívio público. Foto: Eugenio Fernandes Queiroga - 2012.

Os espaços de manifestação da esfera pública geral não podem ser apenas constituídos espontaneamente e desfeitos quando interessar aos incorporadores imobiliários a construção de novos empreendimentos que enfraquecem a vida pública. É luta a ser travada em todos os campos políticos, da vizinhança ao congresso, da ação judiciária à busca de novos direitos - à cidade, ao entorno e à paisagem.

A relevância e a valorização das dimensões públicas da razão comunicativa e da paisagem não são apenas assuntos acadêmicos. $\bigcirc$ tema começa a constituir-se em prática no país notadamente em lugares periféricos, mas não só neles (figura 14).

Inspirado pela esperança presente em grandes mestres, diante dos novos desafios, finalizo citando Milton Santos (1996, p. 206): "Nas condições atuais, as relações informacionais transportam com elas o reino das necessidades, enquanto as relações comunicacionais podem apontar para o reino da liberdade." 


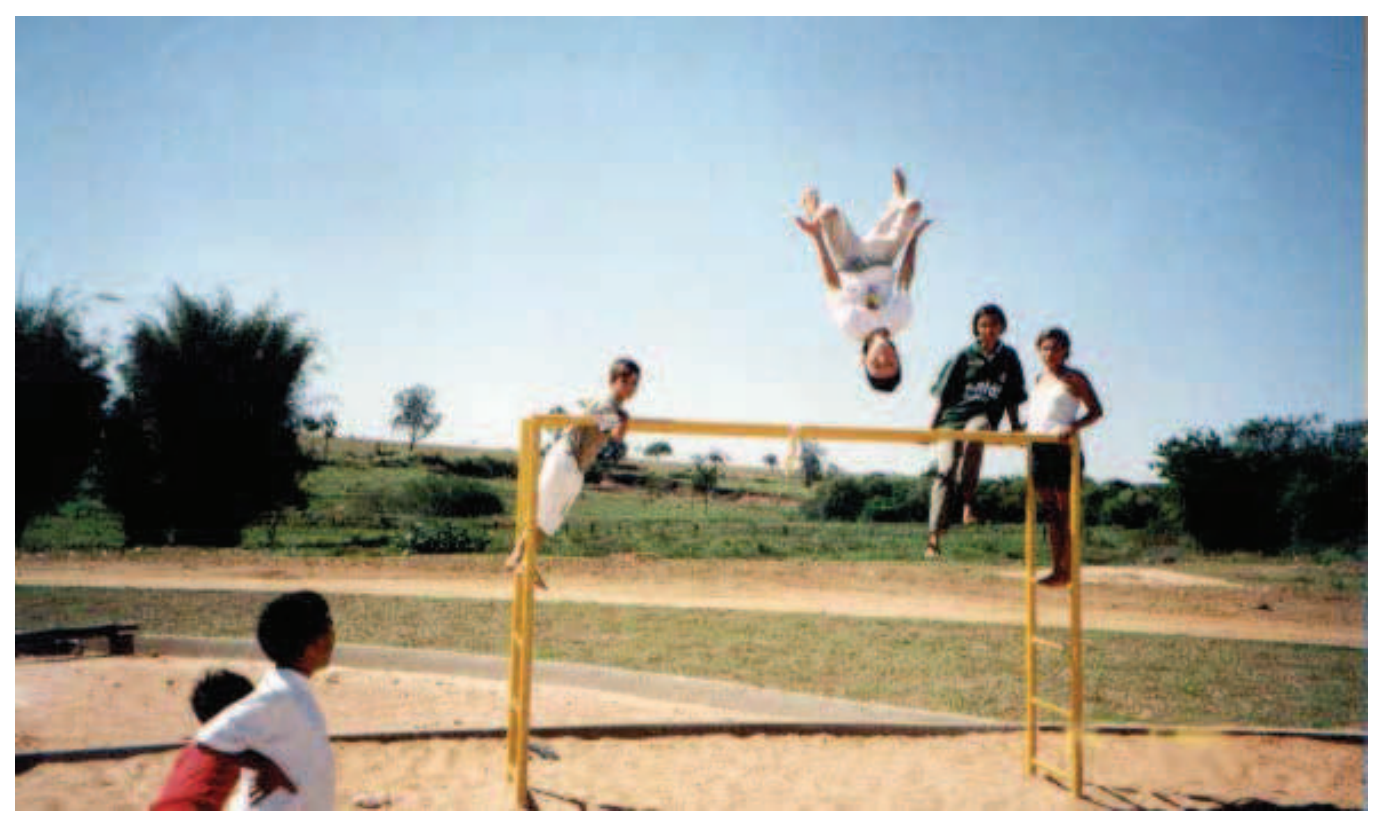

Figura 14 Espaço livre e de liberdade. Praça na periferia de Tambaú, pequena cidade do interior de São Paulo. Foto: Vanessa Figueiredo - 2000.

\section{REFERÊNCIAS BIBLIOGRÁFICAS}

ARENDT, Hannah. A condição humana [1958]. 5 ed. Tradução de Roberto Raposo. Rio de Janeiro: Forense Universitária, 1991. 352 p.

AVRITZER, Leonardo; COSTA, Sérgio. Teoria crítica, democracia e esfera pública: concepções e usos na América Latina. Instituto de Estudos Sociais e Políticos da Universidade do Estado do Rio de Janeiro (IESP/UERJ): Revista Dados, Rio de Janeiro, v. 47, n. 4, 2004, p. 703-728.

HABERMAS, Jürgen. Mudança estrutural da esfera pública: investigações quanto a uma categoria da sociedade burguesa [1962]. Tradução de Flávio Kothe. Rio de Janeiro: Tempo Brasileiro, 1984. 397 p.

. The theory of communicative action [1983]. Translated by Thomas Maccarthy. Boston: Beacon Press, 1987. vol. 2. Lifeworld and system: a critique of functionalist reason. v. 2.

. O discurso filosófico da modernidade [1985]. Tradução de Ana Maria Bernardo et al. Lisboa: Dom Quixote, 1990.540 p.

. Direito e democracia: facticidade e validade [1992]. 2 ed. Tradução de Flávio Siebeneichler. Rio de Janeiro: Tempo Brasileiro, 2003. 2 v.

. A inclusão do outro: estudos de teoria política [1996]. 3 ed. Tradução de George Sperber, Paulo Soethe, Milton Mota. São Paulo: Loyola, 2007. 404 p.

. A constelação pós-nacional: ensaios políticos [1998]. Tradução de Márcio Seligmann-Silva. São Paulo: Littera Mundi, 2001. $220 \mathrm{p}$.

Entre naturalismo y religión [2005]. Traducción de Pere Fabra et al. Barcelona: Paidós, 2006. 363 p.

LEFEBVRE, Henri. The production of space [1974]. 2 ed. Tradução de Donald Nicholson-Smith. Malden-MA: Blackwell, 2009. 454 p.

LEITE, Maria Angela. As tramas da segregação: privatização do espaço público. 1998. 91 f. Tese (Livre-Docência em Arquitetura e Urbanismo) - Faculdade de Arquitetura e Urbanismo da Universidade de São Paulo, São Paulo, 1998.

LEITE, Rogério Proença. Contra-usos da cidade: lugares e espaço público na experiência urbana contemporânea. Campinas: Editora da UNICAMP; Aracaju: Editora da UFS, 2004. 360 p.

PESSOA, Fernando. Obra poética. 3 ed. Rio de Janeiro: Nova Aguilar, 2005. 183 p. 
QUEIROGA, Eugenio. Por um paisagismo crítico: uma leitura sobre a contribuição de Miranda Magnoli para a ampliação do corpus disciplinar do paisagismo. Paisagem e Ambiente: ensaios, n. 21 , 2006. São Paulo: Faculdade de Arquitetura e Urbanismo da Universidade de São Paulo, p. 55-63.

SANTOS, Milton. A natureza do espaço: técnica e tempo, razão e emoção. São Paulo: Hucitec, 1996. 308 p.

Por uma outra globalização: do pensamento único à consciência universal. Rio de Janeiro: Record, 2000. $174 \mathrm{p}$

SENNETT, Richard. O declínio do homem público: as tiranias da intimidade [1974]. Tradução de Lígia Watanabe. São Paulo: Companhia das Letras, 1988. 447 p.

\section{AGRADECIMENTOS}

Agradeço ao Conselho Nacional de Desenvolvimento Científico e Tecnológico (CNPq) pela bolsa de Produtividade em Pesquisa, aos amigos do Lab QUAPÁ, da FAUUSP, cujas críticas e interlocuções acadêmicas são por demais valiosas, e ao Prof. Dr. Gutemberg Weingartner, cujo convite para realizar a palestra inicial do $11^{\circ}$ Encontro Nacional de Ensino de Paisagismo em Escolas de Arquitetura e Urbanismo no Brasil (ENEPEA) estimulou o aprofundamento de reflexões sobre relações entre paisagem, esfera pública e urbanização contemporânea brasileira. 